\title{
Agricultural answers and chemical composition of Massai grass under different nitrogen doses and urea sources ${ }^{1}$
}

\section{Respostas agronômicas e de composição química do capim Massai sob diferentes doses de nitrogênio e fontes de ureia}

\author{
Aline Barros da Silva ${ }^{2 *}$; Carlos Augusto Brandão de Carvalho ${ }^{3}$; \\ Danilo Antonio Morenz $z^{4}$; Pedro Henrique Ferreira da Silva; \\ Alex Junio dos Santos ${ }^{6}$; Fábio Costa dos Santos ${ }^{6}$
}

\begin{abstract}
Under the hypothesis that modifying nitrogen sources and doses could increase nitrogen fertilization efficiency and productivity and improve forage quality, this study aimed to evaluate the morphological composition, structural characteristics and chemical composition of Panicum maximum cv. Massai forage cultivated under different urea sources (common and coated with Policote ${ }^{\circledR}$ ) and nitrogen doses (200, 400 and $600 \mathrm{~kg} \mathrm{ha}^{-1}$ year $\left.{ }^{-1}\right)$ during the autumn, winter and spring of 2014 and the summer and autumn of 2015. The experiment was carried out in Seropédica, RJ, under a randomized complete block design in a factorial arrangement $(3 \times 2)+1$ with four replications. High nitrogen rates promoted higher percentages of leaf blade dry mass and lower percentages of dead material dry mass in the forage mass and provided higher tiller population density and forage accumulation rate of Massai grass during the studied seasons. The use of coated urea promoted higher levels of crude protein in the forage than did the use of common urea in all seasons. The intensification of nitrogen fertilization reduced the nitrogen use efficiency but benefitted the structural characteristics, forage accumulation and chemical composition of Massai grass forage. The use of coated urea promoted greater of nitrogen use efficiency during all seasons of the year.
\end{abstract}

Key words: Coated urea. Nitrogen fertilization. Panicum maximum. Seasons of the year.

\section{Resumo}

Sob a hipótese de aumento da eficiência da adubação nitrogenada quanto ao uso de diferentes fontes e doses de nitrogênio, aliado à maior produtividade e qualidade da forragem produzida, este trabalho foi conduzido com objetivo de avaliar a composição morfológica, as características estruturais e a composição química da forragem do Panicum maximum cv. Massai, cultivado sob diferentes fontes de

1 Parte da Dissertação de Mestrado do primeiro autor.

2 Discente, Curso de Doutorado do Programa de Pós-Graduação em Zootecnia, Universidade Federal Rural do Rio de Janeiro, UFRRJ, Seropédica, RJ, Brasil. E-mail: aline_barros2006@hotmail.com

3 Prof. Dr., Departamento de Nutrição Animal e Pastagem, UFRRJ, Seropédica, RJ, Brasil. E-mail: carloscarvalho_ufrrj@yahoo. com.br

4 Dr. em Zootecnia,Instituto de Zootecnia, UFRRJ, Seropédica, RJ, Brasil. E-mail: danilo.morenz@gmail.com

5 Discente, Curso de Doutorado do Programa de Doutorado Integrado em Zootecnia, Universidade Federal Rural de Pernambuco, UFRPE, Recife, PE, Brasil. E-mail: pehenrique1709@gmail.com

6 Discentes, Curso de Graduação em Zootecnia, UFRRJ, Seropédica, RJ, Brasil.E-mail: alexjunioagro@gmail.com; fabioczootec@ gmail.com

* Author for correspondence

Received: May 06, 2017 - Approved: Jan. 01, 2018 
ureia (comum e revestida por Policote ${ }^{\circledR}$ ) e doses de nitrogênio $\left(200,400\right.$ e $600 \mathrm{~kg} \mathrm{ha}^{-1}$ ano $\left.^{-1}\right)$, durante as estações de outono, inverno e primavera de 2014, verão e outono de 2015. O experimento foi conduzido em Seropédica, RJ, sob delineamento de blocos completos casualizados em arranjo fatorial $(3 \times 2)+1$, com quatro repetições. $\mathrm{O}$ incremento de doses de nitrogênio promoveu maiores porcentagens de massa seca de lâminas foliares e menores porcentagens de material morto na massa de forragem, além de maiores densidades populacionais de perfilhos e taxa de acúmulo de forragem do capim Massai, durante as estações. O uso da ureia revestida promoveu maiores teores de proteína bruta na forragem que a ureia comum em todas as estações. A intensificação da adubação nitrogenada reduz a eficiência do uso de nitrogênio, mas beneficia as características estruturais, o acúmulo de forragem, e a composição química do capim Massai. O uso de ureia revestida promove maior eficiência da utilização do nitrogênio durante todas as estações do ano.

Palavras-chave: Adubação nitrogenada. Estações do ano. Panicum maximum. Ureia revestida.

\section{Introduction}

Reconciling high forage yield and perennial pasture requires adequate management of defoliation and the establishment of a balance that respects the specific limits of each forage species under different sources and doses of fertilizers, concomitant with the conservation of the environment.

In this context, it is known that pasture fertilization is an important strategy aimed at increasing productivity and competitiveness in livestock and that several technological alternatives have been proposed in recent years, among which nitrogen fertilization is the most important. However, the use of nitrogen fertilizers by farmers is still limited, mainly due to fertilizer cost due to the size of the areas involved and the need for frequent applications, in addition to the possible losses when not associated with the fraction incorporated by microorganisms and plants (VITOR et al., 2008), which justifies the study of the effect of different sources and doses of $\mathrm{N}$ on the different crops in the different environments in which they are cultivated.

In addition, in nitrogen systems, nitrogen fertilization also aims to increase the sustainability of the plant community, and the search for sources that provide $\mathrm{N}$ with less loss encourages the application of fertilizers that contribute to increase the nitrogen use efficiency. These fertilizers act by releasing nutrients in a controlled manner according to the needs of the plants. After application, the water-borne fertilizer penetrates the interior of the granule and condenses the solid fertilizer; then, partial dissolution of the nutrients occurs. The mechanism of nutrient release depends on the chemical characteristics of the coating, the thickness, the coating process and the agronomic conditions (AZEEM et al., 2014). These fertilizers have shown promising results in crops such as rice (GAO et al., 2015), potato (ZIADI et al., 2011; WILSON et al., 2009), corn (GAGNON et al., 2012; GRANT et al., 2012; KAPPES et al., 2009), citrus orchards (GIRARDI; MOURÃO FILHO, 2003), and wheat (NASH et al., 2012; YANG et al., 2011).

However, evaluations of these $\mathrm{N}$ sources in forage plants and/or in pastures are still scarce (SANTINI et al., 2016), and even rarer are studies that evaluate these fertilizers for longer periods, as in the case of cycles of pasture use, which require this nutrient throughout the year.

Nitrogen fertilization influences the distribution and arrangement of pasture structural components such as plant height, morphological composition, tiller density and leaf:stem ratio. In addition to the accumulation and nutritional value of the forage, these characteristics are of great relevance for assisting in the management of defoliation since they are indispensable for the establishment of management practices that promote the perennial dominance of desirable forage species (CASTAGNARA et al., 2011).

In this context, the present study was carried out with the objective of evaluating the effects of 
different urea sources and nitrogen doses on the structural characteristics, forage accumulation and nutritional value of Massai grass during the autumn, winter and spring of 2014 and the summer and autumn of 2015 .

\section{Materials and Methods}

This experiment was conducted at the Animal Science Institute of the Federal Rural University of Rio de Janeiro, Seropédica - RJ, at $22^{\circ} 45^{\prime}$ south latitude and $43^{\circ} 41^{\prime}$ west longitude and at 33 meters altitude. The climate in the region is AW (Köppen), with a dry season from April to September and a hot and rainy season from October to March. Meteorological data on precipitation, air temperature and water balance of the experimental period (April 2014 to August 2015) are presented in Table 1.

Table 1. Mean temperatures maximum and minimum, rain total precipitation and water balance during the april 2014 to august 2015.

\begin{tabular}{lccccc}
\hline \multirow{2}{*}{ Month/ Year } & \multicolumn{2}{c}{ Air Temperature $\left({ }^{\circ} \mathrm{C}\right)$} & \multirow{2}{*}{ Precipitation $(\mathrm{mm})$} & \multicolumn{2}{c}{${ }^{1}$ Hídric monthly balance $(\mathrm{mm})$} \\
\cline { 2 - 3 } & Maximum & Minimum & & Deficit & Excess \\
\hline April/ 2014 & 28.9 & 19.9 & 23 & -77.0 & 0 \\
May/ 2014 & 27.7 & 17.8 & 157 & 0 & 64.0 \\
June/ 2014 & 27.6 & 18.1 & 202 & 0 & 110.0 \\
July/2014 & 25.6 & 16.6 & 97 & 0 & 24.0 \\
August/ 2014 & 27.5 & 16.5 & 43 & -53.0 & 0 \\
September/ 2014 & 29.8 & 18.6 & 47 & -73.0 & 0 \\
October/ 2014 & 30.6 & 19.0 & 21 & -111.0 & 0 \\
November/2014 & 30.9 & 20.9 & 79 & -46.0 & 0 \\
December/2014 & 33.4 & 22.3 & 105 & -56.0 & 0 \\
January/2015 & 35.6 & 23.5 & 38 & -162.0 & 0 \\
February/ 2015 & 33.3 & 23.0 & 67 & -89.0 & 0 \\
March/2015 & 31.0 & 22.0 & 5 & -115.0 & 0 \\
April / 2015 & 29.3 & 20.2 & 34 & -71.0 & 0 \\
May/ 2015 & 27.6 & 18.4 & 43 & -47.0 & 0 \\
June/ 2015 & 27.2 & 16.9 & 45 & -46.0 & 0 \\
July/ 2015 & 27.8 & 18.0 & 45 & -49.0 & 0 \\
August/ 2015 & 29.7 & 17.1 & 7 & -119.0 & 0 \\
\hline
\end{tabular}

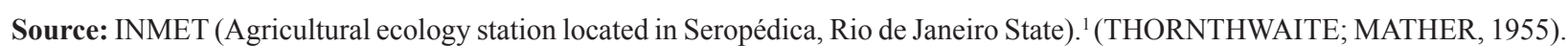

The soil of the experimental area was classified as Haplic Planosol (RAMOS et al., 1973), and after being sampled on 4/2/2014 (before the start of the experiment), the following chemical analysis results were obtained: $\mathrm{pH}\left(\mathrm{H}_{2} \mathrm{O}\right)=6.0 ; \mathrm{OM}=15.3 \mathrm{~g}$ $\mathrm{dm}^{-3} ; \mathrm{Ca}=2.05 \mathrm{cmol}_{\mathrm{c}} \mathrm{dm}^{-3} ; \mathrm{Mg}=0.98 \mathrm{cmol}_{\mathrm{c}} \mathrm{dm}^{-3}$; $\mathrm{K}=0.07 \mathrm{cmol}_{\mathrm{c}} \mathrm{dm}^{-3} ; \mathrm{Na}=0.06 \mathrm{cmol}_{\mathrm{c}} \mathrm{dm}^{-3} ; \mathrm{H}+\mathrm{Al}$ $=1.98 \mathrm{cmol}_{\mathrm{c}} \mathrm{dm}^{-3} ; \mathrm{P}\left(\right.$ Mehlich 1) $=17 \mathrm{mg} \mathrm{dm}^{-3}$; $\mathrm{CTC}=5.14 \mathrm{cmol}_{\mathrm{c}} \mathrm{dm}^{-3}$ and $61 \%$ base saturation . Based on these results, the experimental units were fertilized with $80 \mathrm{~kg} \mathrm{ha}^{-1}$ of $\mathrm{P}_{2} \mathrm{O}_{5}$ in the form of single superphosphate on $04 / 14 / 2014$, according to recommendations of Portz et al. (2013).

The experiment was designed in randomized complete blocks under a factorial arrangement $(3 \times 2)+1$, represented by three doses of $\mathrm{N}(200,400$, $600 \mathrm{~kg} \mathrm{ha}^{-1}$ year $^{-1}$ ), two sources of urea (common and coated with Policote ${ }^{\circledR}$ ) and a control treatment (without fertilization with nitrogen) during the autumn, winter and spring of 2014 and the summer and autumn of 2015 (under a procedure of repeated measures over time). 
$\mathrm{N}$ doses were fractionated into five equal applications throughout the year, three from winter to spring and two from summer to autumn, and applied 10 days after forage crop cutting. Maintenance treatments were performed with urea (common and coated) only for treatments with $\mathrm{N}$ and with potassium chloride $\left(600 \mathrm{~kg} \mathrm{~K}_{2} \mathrm{O} \mathrm{ha}^{-1}\right.$ year $\left.{ }^{1}\right)$ for all treatments (including control) in five plots during the experimental period. The experimental unit was represented by the useful area $\left(3 \mathrm{~m}^{2}\right)$ and center of each plot $\left(8 \mathrm{~m}^{2}\right)$.

The experimental period started on $04 / 25 / 2014$, when a manual cut of uniformity was carried out in all experimental units $15 \mathrm{~cm}$ from the ground, and ended on 08/05/2015. Therefore, field evaluations and cuts of the Massai grass occurred in the seasons of autumn $1(04 / 25$ to $21 / 06)$, winter (21/06 to $09 / 22$ ) and spring (09/22 to $12 / 21)$, followed by summer (12/21/2014 to $03 / 20 / 2015)$ and autumn 2 (03/20 to $06 / 21 / 2015)$, according to the cut criterion established based on $95 \%$ light interception for each evaluated repeat.

The interception of the photosynthetically active radiation percentage (light intercept - IL) was assessed weekly using a ceptometer apparatus (AccuPAR Linear PAR / LAI ceptometer, Model PAR - 80) with six readings, above and below the forage canopy, in each plot (between 9:00 AM and 2:00 PM) until the IL reached $90 \%$ and every other day thereafter. When the IL of each plot reached $95 \%$, manual cutting of the plants $15 \mathrm{~cm}$ from the soil was performed. Together with the IL reading, height measurements of the sward were also recorded, accounting for 12 measurements per plot, based on the curvatures of the last leaves already expanded, using a ruler graduated in millimeters.

The forage samples were obtained by cutting all the plants contained in the useful area of each experimental unit and then weighing and separating them into two subsamples of approximately $300 \mathrm{~g}$ each. Subsample 1 was fractionated in dead material, pseudo stem (stem + leaf sheath) and leaf blade, and subsample 2 was fractionated in dead material and green material. All fractions of both subsamples (1 and 2) were dried in a forced-air ventilation oven at $55 \pm 5{ }^{\circ} \mathrm{C}$ for 72 hours until constant mass to obtain their respective dry masses.

Morphological compositions were calculated based on the dry mass of each fraction of subsample 1 in the forage mass of the original samples. The leaf blade:stem ratio was obtained by dividing the dry mass of leaf blades by the dry mass of stems. Forage accumulation was estimated based on the sum of the forage masses obtained from each treatment in each season, and the accumulation rates were obtained by dividing the forage accumulation by the period (days) of all cuts of each treatment in each season of the year.

Tiller population densities (tiller $\mathrm{m}^{-2}$ ) were evaluated in subsample 2 by counting the number of tillers in the same and the density calculation based on the dry mass of the sample (tiller $\mathrm{m}^{-2}$ ), followed by obtaining their dry masses.

As the criterion established for the cuts performed was $95 \%$ IL for each replicate (plot), the cuts occurred on different dates between the replicates of each treatment. Therefore, forage accumulation rates were estimated based on the sum of the forage mass values obtained at the intervals of the replicate cuts at each season. On the other hand, the variables of forage mass, dry mass of leaf blades, stem and dead material percentages, and leaf blade:stem ratio were estimated based on the average values obtained in each cut of the repetitions. For the variables height, tiller population density, and those of chemical composition of the forage, there was no evaluation in autumn 1 because no cut occurred in this season as the canopies did not meet the criterion (95\% IL).

The nitrogen use efficiency (NUE) was calculated as follows: $\mathrm{NUE}=[($ forage accumulation of the fertilized treatment - forage accumulation of the control treatment) / $\mathrm{N}$ dose applied of each treatment in each season, in $\mathrm{kg} \mathrm{ha}^{-1}$. This variable 
was also calculated in proportion to the seasons, as described above for the forage mass.

The dry matter (DM) and crude protein (PB) contents of the forage were determined according to AOAC (2000), and the neutral detergent insoluble fiber (NDF) content was determined according to Van Soest et al. (1991) using subsample 2.

The results were submitted to variance analysis using PROC MIXED of SAS ${ }^{\circledR}$, version 9.2. The matrices of variance and covariance were selected according to Akaike's criterion (WOLFINGER, 1993). PROC REG $(p<0.05)$ was used to evaluate the effects of quantitative factors (nitrogen doses) and, for qualitative purposes (urea sources and seasons), the mean values of the treatments, estimated by "LSMEANS" and compared by difference probability ("PDIFF") with 5\% probability.

\section{Results and Discussion}

In the experimental period, there was a water deficit at the beginning of the experiment (April 2014), followed by a surplus period (May to July 2014), when the highest monthly averages were recorded in July (97 mm) and June (202 mm), and a new water deficit during the remainder of the experimental period (August 2014 to August 2015), as presented in Table 1. However, these data are in contrast to those verified by Alcântara and Schueler (2015), who found maximum rainfall in the period from November to April, with monthly averages varying from $196.1 \mathrm{~mm}$ in January to $109.2 \mathrm{~mm}$ in April, based on 30 years climatic data (1984 to 2014) obtained from INMET for Seropédica, RJ.

In the present study, the highest $(339 \mathrm{~mm})$ and the lowest $(130 \mathrm{~mm})$ values of accumulated mean precipitation occurred in the seasons autumn of 2014 and autumn of 2015 (periods from April to June of the respective years). This behavior was also considered atypical when compared to that described by Oliveira Júnior et al. (2014), who evaluated the seasonal distribution of 10 years of data (2002 to
2012) obtained from INMET to Seropédica, RJ, and verified that in the summer (December to February), the highest average values of accumulated mean precipitation were $250 \mathrm{~mm}$, and the lowest were in winter (June to August), below $50 \mathrm{~mm}$. In addition, the fluctuations between minimum and maximum air temperatures for autumn, winter and spring of 2014 and summer and autumn of 2015 were higher than those commonly found in the literature for Seropédica (CARVALHO et al., 2011).

There was an effect $(p<0.05)$ of interaction between dose, nitrogen source and season on forage mass, dry mass of leaf blades and dead material percentage (Table 2).

It is worth noting that the highest effect observed for the use of coated urea (linear effects) in relation to common urea (quadratic effects) on forage mass in autumn 1 and 2 was due to the polymer coating promoting greater release control (Table 1). However, it is important to note that there was a significant reduction in the number of rainfall events during the rainy season. In summer, the greatest effect of the use of common urea (linear effect) was due to the lower rainfall and high water deficit, which contributed to the loss of leaching of the common urea. This possibly favored the higher growth rate of the plants according to the need for a more readily available $\mathrm{N}$ source. In contrast, for coated urea, the release of nitrogen into the soil solution depends on the dissolution and diffusion in the fertilizer granules, making it less efficient than the common urea in this situation.

The greater participation of leaf blades in the forage mass verified in the spring of 2014 and summer of 2015 (Table 2) for both sources of urea was due to the higher frequency of cuts (up to three cuts in the same season) when compared to the others, due to the high temperatures and the increase in the precipitation that favored the growth of the plants, together with the better utilization of the nitrogen fertilizer, accelerating tissue renewal, tillering and production of leaf blades, as highlighted by Lopes 
et al. (2011). The average proportion of leaf blades in relation to the total forage produced in the present experiment $(82.0 \%)$ was similar to that obtained by Emerenciano Neto et al. (2016) and higher than the $63 \%$ observed by Emerenciano Neto et al. (2013), both for Massai grass. These differences can be explained both by the criterion of the cut, as well as by the climatic conditions (solar radiation, rainfall index and temperatures) and soil characteristics of each region where the experiments were carried out.

Table 2. Forage mass and leaf blade and dead material dry masses percentages of Massai grass as a function of urea sources; nitrogen doses; and the seasons autumn (autumn 1), winter and spring of 2014 and summer and autumn (autumn 2) of 2015.

\begin{tabular}{|c|c|c|c|c|c|c|c|c|}
\hline \multirow{2}{*}{ Season } & \multicolumn{6}{|c|}{ N Doses $\left(\mathrm{kg} \mathrm{ha}^{-1} \mathrm{yr}^{-1}\right)$} & \multirow{2}{*}{ Equations } & \multirow{2}{*}{$\mathrm{R}^{2}$} \\
\hline & 0 & Urea & 200 & 400 & 600 & SEM & & \\
\hline \multicolumn{9}{|c|}{ Forage mass $\left(\mathrm{kg} \mathrm{ha}^{-1}\right)$} \\
\hline \multirow{2}{*}{ Autumn 1} & \multirow{2}{*}{$1018^{\mathrm{D}}$} & Common & $2569^{\mathrm{B}}$ & $1994^{\mathrm{C}}$ & $2323^{\mathrm{BC}}$ & \multirow{2}{*}{129} & $\hat{Y}=1169.8+6$. & 0.58 \\
\hline & & Coated & $2256^{\mathrm{BC}}$ & $2207^{\mathrm{C}}$ & $3228^{A}$ & & $\hat{Y}=1190.5+3.2$ & 0.78 \\
\hline \multirow{2}{*}{ Winter } & \multirow{2}{*}{$1766^{D}$} & Common & $2348^{\mathrm{AB}}$ & $2277^{\mathrm{B}}$ & $2648^{\mathrm{A}}$ & \multirow{2}{*}{118} & $\hat{Y}=1873.4+1.287 X * *$ & 0.55 \\
\hline & & Coated & 1864 CD & $2155^{\mathrm{BC}}$ & $2260^{\text {В }}$ & & $\hat{Y}=1745.1+0.8868 X *$ & 0.39 \\
\hline \multirow{2}{*}{ Spring } & \multirow{2}{*}{$1453^{\mathrm{D}}$} & Common & $2878^{\mathrm{AB}}$ & $2778^{\mathrm{ABC}}$ & $3167^{\mathrm{AB}}$ & \multirow{2}{*}{206} & $\hat{\mathrm{Y}}=1812.2+2.5218 \mathrm{X}^{* *}$ & 0.51 \\
\hline & & Coated & $2231^{\mathrm{C}}$ & $2679^{\mathrm{BC}}$ & $3342^{\mathrm{A}}$ & & $\hat{Y}=1508.9+3.05$ & 0.75 \\
\hline \multirow{2}{*}{ Summer } & \multirow{2}{*}{$2396^{\mathrm{C}}$} & Common & $3981^{\mathrm{AB}}$ & $3488^{\mathrm{B}}$ & $4309^{\mathrm{A}}$ & \multirow{2}{*}{270} & $\hat{\mathrm{Y}}=2677.6+2.7214 \mathrm{X} * *$ & 0.47 \\
\hline & & Coated & $4186^{\mathrm{AB}}$ & $3603^{\mathrm{AB}}$ & $3544^{\mathrm{B}}$ & & $\hat{Y}=2$ & 0.43 \\
\hline \multirow{2}{*}{ Autumn 2} & \multirow{2}{*}{$1317^{\mathrm{D}}$} & Common & $2477^{\mathrm{AB}}$ & $2104^{\mathrm{C}}$ & $2486^{\mathrm{AB}}$ & \multirow{2}{*}{131} & $\hat{\mathrm{Y}}=1431.7+4.48 \mathrm{X}-0.0049 \mathrm{X}^{2} *$ & 0.57 \\
\hline & & Coated & $2102^{\mathrm{C}}$ & $2257^{\mathrm{BC}}$ & $2686^{\mathrm{A}}$ & & $\hat{Y}=1451.2+2.1305 X * *$ & 0.70 \\
\hline \multicolumn{9}{|c|}{ Leaf blade dry mass percentage (\% FM) } \\
\hline \multirow{2}{*}{ Autumn 1} & \multirow{2}{*}{$68.4^{\mathrm{D}}$} & Common & $89.0^{\mathrm{AB}}$ & $90.4^{\mathrm{A}}$ & $89.1^{\mathrm{AB}}$ & \multirow{2}{*}{1,6} & $\hat{\mathrm{Y}}=69.2+0.11 \mathrm{X}-0$ & 0.86 \\
\hline & & Coated & $84.8^{\mathrm{BC}}$ & $85.9^{\mathrm{ABC}}$ & $81.9^{\mathrm{C}}$ & & $\hat{Y}=6$ & 0.76 \\
\hline \multirow{2}{*}{ Winter } & \multirow{2}{*}{$67.0^{\mathrm{D}}$} & Common & $76.5^{\mathrm{C}}$ & $79.4 \mathrm{BC}$ & $77.9^{\mathrm{BC}}$ & \multirow{2}{*}{1,5} & $\hat{\mathrm{Y}}=67.1+0.059 \mathrm{X}-0.0001 \mathrm{X}^{2 * *}$ & 0.74 \\
\hline & & Coated & $82.0^{\mathrm{B}}$ & $81.4^{\mathrm{B}}$ & $88.4^{\mathrm{A}}$ & & $\hat{Y}=70.1+0.0318 X * *$ & 0.72 \\
\hline & $826 \mathrm{C}$ & Common & $78.3^{\mathrm{D}}$ & $84.7^{\mathrm{B}}$ & $89.3^{\mathrm{A}}$ & & $\hat{\mathrm{Y}}=80.2+0.0098 \mathrm{X} *$ & 0.33 \\
\hline Spring & $82.6^{c}$ & Coat & $84.2^{\mathrm{BC}}$ & $82.3^{\mathrm{C}}$ & $88.8^{\mathrm{A}}$ & 0,8 & $\hat{\mathrm{Y}}=81.9+0.0$ & 0.41 \\
\hline & & Common & $80.2^{\mathrm{D}}$ & $83.9^{\mathrm{BC}}$ & $82.4^{\mathrm{CD}}$ & & $\hat{\mathrm{Y}}=82.1$ & - \\
\hline Summer & 2 & Coated & $82.9^{\mathrm{BCD}}$ & $88.3^{\mathrm{A}}$ & $86.0^{\mathrm{AB}}$ & 1,2 & $\hat{Y}=82.3+0.00$ & 0.33 \\
\hline 2 & $634 \mathrm{CD}$ & Common & $77.8^{\mathrm{A}}$ & $74.5^{\mathrm{AB}}$ & $69.0^{\mathrm{BC}}$ & 22 & $\hat{\mathrm{Y}}=64.2+0.081 \mathrm{X}-0.0001 \mathrm{X}^{2 *}$ & 0.57 \\
\hline Autumn 2 & 03.4 & Coated & $65.8^{\mathrm{CD}}$ & $65.5^{\mathrm{CD}}$ & $61.8^{\mathrm{D}}$ & 2,2 & $\hat{Y}=64.1$ & - \\
\hline & & & Dead 1 & aterial $\mathrm{dr}$ & mass per & & o FM) & \\
\hline & & Common & $2.4^{\mathrm{DE}}$ & $4.9^{\mathrm{D}}$ & $2.7^{\mathrm{CD}}$ & & $\hat{\mathrm{Y}}=28.6-0.137 \mathrm{X}+0.0002 \mathrm{X}^{2 * *}$ & 0.82 \\
\hline Autumn I & $32.1^{\mathrm{A}}$ & Coated & $3.2^{\mathrm{c}}$ & $3.0^{\mathrm{C}}$ & $1.9^{\mathrm{E}}$ & 0.2 & $\hat{Y}=29.3-0.1422 X+0.0002 X^{2 * *}$ & 0.88 \\
\hline & & Common & $15.4^{\mathrm{BC}}$ & $14.3^{\mathrm{C}}$ & $16.2^{\mathrm{B}}$ & & $\hat{\mathrm{Y}}=31.0-0.094 \mathrm{X}+0.0001 \mathrm{X}^{2} * *$ & 0.93 \\
\hline ter & $31.8^{\mathrm{A}}$ & Coated & $7.9^{\mathrm{E}}$ & $10.1^{\mathrm{D}}$ & $3.9^{\mathrm{F}}$ & .5 & $\hat{Y}=29.3-0.0998 X+0.0001 X^{2 * *}$ & 0.82 \\
\hline & & Common & $11.3^{\mathrm{A}}$ & $5.8^{\mathrm{C}}$ & $3.9^{\mathrm{D}}$ & & $\hat{\mathrm{Y}}=11.8-0.013 \mathrm{X} * *$ & 0.73 \\
\hline Spring & 10 & Coated & $9.2^{\text {в }}$ & $9.2^{\text {в }}$ & $2.7^{\mathrm{D}}$ & 0.6 & $\hat{\mathrm{Y}}=11.3-0.0116 \mathrm{X} * *$ & 0.67 \\
\hline & & Common & $1.2^{\mathrm{DE}}$ & $1.8^{\mathrm{C}}$ & $2.5^{\mathrm{B}}$ & & $\hat{\mathrm{Y}}=3.6-0.0137 \mathrm{X}+0.0000203 \mathrm{X}^{2 * *}$ & 0.74 \\
\hline imer & 3. & Coated & $1.2^{\mathrm{DE}}$ & $0.8^{\mathrm{E}}$ & $1.7^{\mathrm{CD}}$ & 2.3 & $\hat{Y}=3.7-0.016 X+0.0000213 X^{2 * *}$ & 0.83 \\
\hline & & Common & $3.1^{\mathrm{D}}$ & $6.1^{\mathrm{C}}$ & $5.0^{\mathrm{C}}$ & & $\hat{\mathrm{Y}}=19.7-0.0854 \mathrm{X}+0.0001 \mathrm{X}^{2} * *$ & 0.75 \\
\hline Autumn 2 & 2 & Coated & $7.5^{\mathrm{B}}$ & $3.6^{\mathrm{D}}$ & $1.9^{\mathrm{E}}$ & .5 & $\hat{Y}=21.6-0.077 X+0.0001 X^{2 * *}$ & 0.97 \\
\hline
\end{tabular}

Mean values within the same station followed by the same capital letter do not differ by PDIFF ( $>00.05$ ). SEM: Standard error of the mean. Autumn 1 (4/25/2014 to 6/21/2014), Winter (6/21/2014 to $9 / 22 / 2014)$, Spring (9/22/2014 to 12/21/2014, Summer 2014 $(12 / 21 / 2014$ to $03 / 20 / 2015)$ and Autumn $2(03 / 20 / 2015$ to $06 / 21 / 2015) .{ }^{*}(\mathrm{p}<0.05)$ and $* *(\mathrm{p}<0.01)$. 
The highest values of dead material dry mass were obtained for the control treatment in all seasons, while the lowest values did not show a pattern of occurrence for doses or sources of urea within each season. The dead material dry mass percentages were less than 16\% (greater than in the winter season and of the whole experiment) in the forage mass and well below the 63 and $62 \%$ obtained in the experiments of Emerenciano Neto et al. (2013) and Euclides et al. (2008) for this same variable, respectively. This shows good control of the canopy structure under Massai grass cutting by light interception (95\% IL), even considering the edaphoclimatic differences between experiments. In addition, the effect of increased nitrogen fertilization on the reduction of the values of this variable was evident for both sources of urea in all seasons, possibly due to the greater growth of the plants and accumulation of fodder and consequently less time needed to reach the established cut criterion $(95 \%$ of IL) and remain under auto-shading, leading to the lower accumulation of dead material in relation to the control treatment.

There was an interaction $(\mathrm{p}<0.05)$ between nitrogen doses and seasons of the year for height and tiller population density (Table 3 ). Higher values of height were verified during the summer season, and only for the control treatment were lower values in autumn $2(44 \mathrm{~cm})$ and winter $(48 \mathrm{~cm})$, respectively. There was a negative linear effect during summer and spring, and there was no effect of $\mathrm{N}$ dose during autumn/winter $(47 \mathrm{~cm})$ and autumn $2(48 \mathrm{~cm})$. This is due to the high temperatures, small increase in rainfall (Table 1) and favorable conditions of solar radiation of the summer season, which favor the growth and production of $\mathrm{C}_{4}$ plants (LAWLOR, 1987).

Table 3. Height and tiller population density of the Massai grass canopy as a function of nitrogen (common and Policote ${ }^{\circledR}$ urea), in autumn/winter and spring of 2014 and summer and autumn 2 of 2015.

\begin{tabular}{|c|c|c|c|c|c|c|c|}
\hline \multirow{2}{*}{ Season } & \multicolumn{4}{|c|}{$\mathrm{N}$ doses $\left(\mathrm{kg} \mathrm{ha}^{-1} \mathrm{yr}^{-1}\right)$} & \multirow{2}{*}{ SEM } & \multirow{2}{*}{ Equations } & \multirow{2}{*}{$\mathrm{R}^{2}$} \\
\hline & 0 & 200 & 400 & 600 & & & \\
\hline \multicolumn{8}{|c|}{ Height $(\mathrm{cm})$} \\
\hline Autumn/winter & $48^{\mathrm{C}}$ & $50^{\mathrm{B}}$ & $45^{\mathrm{B}}$ & $46^{\mathrm{B}}$ & 2 & $\hat{\mathrm{Y}}=47$ & - \\
\hline Spring & $62^{\mathrm{B}}$ & $54^{\mathrm{B}}$ & $50^{\mathrm{B}}$ & $47^{\mathrm{B}}$ & 2 & $\hat{\mathrm{Y}}=60.115-0.0235 \mathrm{X}^{* *}$ & 0.40 \\
\hline Summer & $81^{\mathrm{A}}$ & $66^{\mathrm{A}}$ & $57^{\mathrm{A}}$ & $59^{\mathrm{A}}$ & 4 & $\hat{Y}=75-0.0334 X^{* *}$ & 0.47 \\
\hline Autumn 2 & $44^{\mathrm{D}}$ & $50^{\mathrm{B}}$ & $47^{\mathrm{B}}$ & $50^{\mathrm{B}}$ & 3 & $\hat{\mathrm{Y}}=48$ & - \\
\hline \multicolumn{8}{|c|}{ Tiller population density (tiller $\mathrm{m}^{-2}$ ) } \\
\hline Autumn/winter & $216^{\mathrm{B}}$ & $751^{\mathrm{B}}$ & $968^{\mathrm{AB}}$ & $1148^{\mathrm{A}}$ & 108 & $\hat{\mathrm{Y}}=352.94+1.3345 \mathrm{X}^{* *}$ & 0.51 \\
\hline Spring & $473^{\mathrm{A}}$ & $738^{\mathrm{B}}$ & $777^{\mathrm{B}}$ & $963^{\mathrm{A}}$ & 64 & $\hat{\mathrm{Y}}=532.02+0.71 \mathrm{X}^{* *}$ & 0.39 \\
\hline Summer & $461^{\mathrm{A}}$ & $1025^{\mathrm{A}}$ & $1053^{\mathrm{A}}$ & $1031^{\mathrm{A}}$ & 82 & $\hat{Y}=533.1+2.4934 X-0.0029 X^{2 * *}$ & 0.30 \\
\hline Autumn 2 & $152^{\mathrm{B}}$ & $403^{\mathrm{C}}$ & $376^{\mathrm{C}}$ & $454^{\mathrm{B}}$ & 45 & $\hat{Y}=247.38+0.3691 X^{*}$ & 0.18 \\
\hline
\end{tabular}

Means arranged in the same column followed by the same capital letter do not differ by PDIFF ( $>0.05)$. SEM: standard error of the mean. Autumn/Winter (04/25/2014 to 09/22/2014), Spring (22/09/2014 to $12 / 21 / 2014)$, Summer (12/21/2014 to 20/03/2015) and Autumn $2(20 / 03 / 2015$ to $21 / 06 / 2015) . *(\mathrm{p}<0.05)$ and $* *(\mathrm{p}<0.01)$.

It is verified that the average height of the canopy $(54 \mathrm{~cm})$ obtained in the experiment at the moment of the cut is within the values already reported in the literature for Massai grass (50 and $60 \mathrm{~cm}$ ) by Emerenciano Neto et al. (2016) under the criterion of fixed days, evidencing good control of the forage canopy structure when cut at the time at which each repetition reached the desired level of IL (95\%). The lowest values obtained in autumn 2 and autumn/winter in relation to summer and spring for the control treatment were probably because the cut was performed even when the Massai grass canopies showed levels of IL below $95 \%$ in these two stations, after three to four weekly follow-up 
evaluations of IL without increasing levels of this intercept for this treatment.

As for height, higher tiller population densities were obtained in the summer, but with lower values in autumn 2 for all $\mathrm{N}$ doses. However, there was a greater variation in the results in relation to the $\mathrm{N}$ doses, especially for the dose of $600 \mathrm{~kg} \mathrm{ha}^{-1}$ year ${ }^{1}$, in which equality between summer, spring and winter was verified. There was a positive linear effect of $\mathrm{N}$ dose during winter, spring and autumn 2 , with a higher fall/winter ( 1.3 tiller $\mathrm{m}^{-2}$ per $\mathrm{N} \mathrm{kg}$ ), and a positive quadratic effect during the summer of 1069 tiller $\mathrm{m}^{-2}$ for the dose of $430 \mathrm{~kg} \mathrm{ha}^{-1}$ year $^{-1} \mathrm{~N}$.

There was an effect $(p<0.05)$ of interaction between dose, urea source and seasons of the year for leaf blade:shoot height ratio, forage accumulation rate of Massai grass, and nitrogen use efficiency during autumn 1, winter and spring of 2014 and summer and autumn of 2015 (Table 4). The values of leaf blade:shoot height ratio of Massai grass (average of 8: 1) are considered high in relation to those obtained for other forage plants, as demonstrated by Brâncio et al. (2003), who evaluated three cultivars of Panicum maximum and reported higher values of leaf blade:stem ratio for cv. Massai grass (7:1) compared to cvs. Tanzania and Mombasa (values between 1:1 and 2:1). These high values of leaf blade:stem ratio of the Massai grass are probably due to the lower weight of their stems, as observed by Brâncio et al. (2003), which implies a higher proportion of leaf blades and better quality of forage produced.

Lower forage accumulation rates were verified for the control treatment during all seasons and were generally higher for the higher $\mathrm{N}$ doses (400 and $600 \mathrm{~kg} \mathrm{ha}^{-1}$ year $^{-1}$ ). In addition, higher forage accumulation rates were also verified during summer and spring in relation to the other seasons. There was a positive linear effect of $\mathrm{N}$ doses for both sources of urea during all seasons. The maximum forage accumulation rate was not obtained in the regression analysis, even under the effect of the maximum $\mathrm{N}$ dose studied $\left(600 \mathrm{~kg} \mathrm{ha}^{-1}\right.$ year $\left.^{-1}\right)$. This is due to the interaction between $\mathrm{N}$ and the cut frequency, in the sense that the former favors the recovery of the plants and the vigor of the tiller, and the second can allow the maintenance of apical meristems, both of which can therefore have beneficial effects on the vigor of regrowth (HILL; WATSON, 1989). According to Hodgson (1990), forage beds submitted to nitrogen fertilization with availability of light incidence directly promote greater development of basal or lateral growth buds, justified by the fact that nitrogen increases the photosynthetic efficiency of the plants and, consequently, the accumulation of forage (MACEDO et al., 2012). The average forage accumulation rates verified in this experiment (60 $\mathrm{kg} \mathrm{ha}^{-1}$ day $\left.^{-1} \mathrm{DM}\right)$ were higher than those obtained by Luna et al. (2014) $\left(56 \mathrm{~kg} \mathrm{ha}^{-1} \mathrm{~d}^{-1} \mathrm{DM}\right)$ and lower those of Emerenciano Neto et al. (2013) $(73 \mathrm{~kg}$ ha $^{-1}$ day $^{-1} \mathrm{DM}$ ), both with Massai grass. However, it should be considered that these values are only referential, since the environmental conditions of the experiments are totally differentiated.

The linear increase in the nitrogen use efficiency (Table 4) in the winter season with the use of coated urea is due to reductions in $\mathrm{N}$ losses, with maintenance of the timing of release of this nutrient according to the needs for growth and development of plants (AZEEM et al., 2014). However, the reduction of the nitrogen use efficiency under higher $\mathrm{N}$ doses (Table 4) is due to the leaching or accumulation of $\mathrm{N}$ in the tissues of plants, as a function of the amount of nutrient applied to the plant exceeds the capacity of the plant to absorb and use it for production (DOUGHERTY; RHYKERD, 1985). 
Table 4. Leaf blade:stem ratio, forage accumulation rate and nitrogen use efficiency of Massai grass as a function of urea sources; nitrogen doses; and the seasons autumn (autumn 1), winter and spring of 2014 and summer and autumn (autumn 2) of 2015.

\begin{tabular}{|c|c|c|c|c|c|c|c|c|}
\hline \multirow{2}{*}{ Season } & \multicolumn{5}{|c|}{$\mathrm{N}$ doses $\left(\mathrm{kg} \mathrm{ha}^{-1} \mathrm{yr}^{-1}\right)$} & \multirow{2}{*}{ SEM } & \multirow{2}{*}{ Equations } & \multirow{2}{*}{$\mathrm{R}^{2}$} \\
\hline & 0 & Urea & 200 & 400 & 600 & & & \\
\hline \multicolumn{9}{|c|}{ Leaf blade: stem ratio } \\
\hline \multirow{2}{*}{ Autumn 1} & \multirow{2}{*}{$14.8^{\mathrm{B}}$} & Common & $10.4^{\mathrm{CD}}$ & $18.0^{\mathrm{A}}$ & $11.4^{\mathrm{C}}$ & \multirow{2}{*}{0.9} & $\hat{\mathrm{Y}}=13.2$ & - \\
\hline & & Coated & $6.2^{\mathrm{E}}$ & $8.5^{\mathrm{DE}}$ & $6.0^{\mathrm{E}}$ & & $\hat{\mathrm{Y}}=14.03-0.035 \mathrm{X}+0.0000381 \mathrm{X}^{2 * *}$ & 0.65 \\
\hline \multirow{2}{*}{ Winter } & \multirow{2}{*}{$13.0^{\mathrm{A}}$} & Common & $9.5^{\mathrm{C}}$ & $10.4^{\mathrm{BC}}$ & $11.9^{\mathrm{AB}}$ & \multirow{2}{*}{0.8} & $\hat{\mathrm{Y}}=11.0$ & - \\
\hline & & Coated & $10.8^{\mathrm{ABC}}$ & $9.4^{\mathrm{C}}$ & $12.6^{\mathrm{AB}}$ & & $\hat{\mathrm{Y}}=11.3$ & - \\
\hline \multirow{2}{*}{ Spring } & \multirow{2}{*}{$12.2^{\mathrm{A}}$} & Common & $7.3^{\mathrm{D}}$ & $9.2^{\mathrm{CD}}$ & $9.7^{\mathrm{BC}}$ & \multirow{2}{*}{0.8} & $\hat{Y}=9.6$ & - \\
\hline & & Coated & $11.4^{\mathrm{AB}}$ & $9.7^{\mathrm{BC}}$ & $10.6^{\mathrm{ABC}}$ & & $\hat{\mathrm{Y}}=11.0$ & - \\
\hline \multirow{2}{*}{ Summer } & \multirow{2}{*}{$6.0^{\mathrm{BC}}$} & Common & $4.5^{\mathrm{D}}$ & $6.0^{\mathrm{BC}}$ & $5.6^{\mathrm{BCD}}$ & \multirow{2}{*}{0.5} & $\hat{\mathrm{Y}}=5.5$ & - \\
\hline & & Coated & $5.4^{\mathrm{CD}}$ & $8.2^{\mathrm{A}}$ & $7.0^{\mathrm{AB}}$ & & $\hat{\mathrm{Y}}=6.6$ & - \\
\hline \multirow{2}{*}{ Autumn 2} & \multirow{2}{*}{$5.2^{\mathrm{A}}$} & Common & $4.2^{\mathrm{A}}$ & $4.2^{\mathrm{A}}$ & $2.8^{\mathrm{B}}$ & \multirow{2}{*}{0.4} & $\hat{\mathrm{Y}}=5.05-0.0039 \mathrm{X}^{* *}$ & 0.60 \\
\hline & & Coated & $2.4^{\mathrm{B}}$ & $2.3^{\mathrm{B}}$ & $1.7^{\mathrm{B}}$ & & $\hat{\mathrm{Y}}=4.43-0.0052 \mathrm{X}^{* *}$ & 0.60 \\
\hline \multicolumn{9}{|c|}{ Forage accumulation rate $\left(\mathrm{kg} \mathrm{ha}^{-1}\right.$ day $\left.^{-1}\right)$} \\
\hline \multirow{2}{*}{ Autumn 1} & \multirow[b]{2}{*}{$18^{\mathrm{D}}$} & Common & $45^{\mathrm{B}}$ & $35^{\mathrm{C}}$ & $41^{\mathrm{BC}}$ & \multirow[b]{2}{*}{2} & $\hat{Y}=25.88+0.0294 X^{*}$ & 0.34 \\
\hline & & Coated & $40^{\mathrm{BC}}$ & $39^{\mathrm{C}}$ & $57^{\mathrm{A}}$ & & $\hat{\mathrm{Y}}=20.8+0.0578 \mathrm{X}^{* *}$ & 0.78 \\
\hline \multirow{2}{*}{ Winter } & \multirow{2}{*}{$30^{\mathrm{E}}$} & Common & $55^{\mathrm{BC}}$ & $47^{\mathrm{CD}}$ & $62^{\mathrm{B}}$ & & $\hat{Y}=35.25+0.0444 X^{* *}$ & 0.53 \\
\hline & & Coated & $41^{\mathrm{D}}$ & $51^{\mathrm{C}}$ & $78^{\mathrm{A}}$ & 3 & $\hat{Y}=26.85+0.0774 X^{* *}$ & 0.81 \\
\hline & & Common & $68^{\mathrm{B}}$ & $62^{\mathrm{B}}$ & $89^{\mathrm{A}}$ & & $\hat{\mathrm{Y}}=40.45+0.0798 \mathrm{X}^{* *}$ & 0.72 \\
\hline Spring & $35^{\mathrm{C}}$ & Coated & $66^{\mathrm{B}}$ & $82^{\mathrm{A}}$ & $86^{\mathrm{A}}$ & 4 & $\hat{Y}=41.65+0.0851 X^{* *}$ & 0.73 \\
\hline & $54 \mathrm{C}$ & Common & $107^{\mathrm{AB}}$ & $111^{\mathrm{A}}$ & $116^{\mathrm{A}}$ & & $\hat{\mathrm{Y}}=62.35+0.1068 \mathrm{X}^{* *}$ & 0.69 \\
\hline Summer & $54^{c}$ & Coated & $93^{\mathrm{B}}$ & $112^{\mathrm{A}}$ & $119^{\mathrm{A}}$ & 6 & $\hat{\mathrm{Y}}=68.55+0.0953 \mathrm{X}^{* *}$ & 0.63 \\
\hline & $30^{\mathrm{C}}$ & Common & $64^{\mathrm{AB}}$ & $60^{\mathrm{AB}}$ & $71^{\mathrm{A}}$ & 5 & $\hat{Y}=38.5+0.0588 X^{* *}$ & 0.50 \\
\hline Autumn 2 & $30^{c}$ & Coated & $55^{\mathrm{B}}$ & $63^{\mathrm{AB}}$ & $72^{\mathrm{A}}$ & 5 & $\hat{\mathrm{Y}}=34.598+0.0674 \mathrm{X}^{* *}$ & 0.71 \\
\hline & & & Nitrog & n use ef & iency ( & $\overline{a^{-1} F}$ & $\mathrm{~h} / \mathrm{N} \mathrm{kg})$ & \\
\hline & & Common & $7.2^{\mathrm{A}}$ & $2.7^{\mathrm{CD}}$ & $2.2^{\mathrm{D}}$ & & $\hat{\mathrm{Y}}=0.79+0.0301 \mathrm{X}-0.0000484 \mathrm{X}^{2 *}$ & 0.53 \\
\hline Autumn 1 & $0.0^{\mathrm{E}}$ & Coated & $6.6^{\mathrm{A}}$ & $3.2^{\mathrm{BC}}$ & $3.8^{\mathrm{B}}$ & 0.3 & $\hat{\mathrm{Y}}=0.70+0.0268 \mathrm{X}-0.0000381 \mathrm{X}^{2} *$ & 0.53 \\
\hline & & Common & $12.8^{\mathrm{A}}$ & $5.2^{\mathrm{C}}$ & $5.4^{\mathrm{C}}$ & & $\hat{\mathrm{Y}}=1.40+0.0517 \mathrm{X}-0.0001 \mathrm{X}^{2} *$ & 0.51 \\
\hline Winter & $0.0^{\mathrm{D}}$ & Coated & $5.4^{\mathrm{C}}$ & $6.2^{\mathrm{C}}$ & $7.4^{\mathrm{B}}$ & 0.4 & $\hat{\mathrm{Y}}=1.30+0.0115 \mathrm{X} * *$ & 0.77 \\
\hline & & Common & $17.8^{\mathrm{A}}$ & $7.2^{\mathrm{C}}$ & $7.4^{\mathrm{C}}$ & & $\hat{\mathrm{Y}}=1.69+0.0657 \mathrm{X}-0.0001 \mathrm{X}^{2} *$ & 0.50 \\
\hline Spring & $0.0^{\mathrm{D}}$ & Coated & $18.3^{\mathrm{A}}$ & $11.9^{\mathrm{B}}$ & $6.9^{\mathrm{C}}$ & 0.5 & $\hat{\mathrm{Y}}=1.13+0.0908 \mathrm{X}-0.0001 \mathrm{X}^{2} * *$ & 0.80 \\
\hline & & Common & $25.0^{\mathrm{A}}$ & $13.7^{\mathrm{C}}$ & $9.2^{\mathrm{D}}$ & & $\hat{\mathrm{Y}}=1.85+0.1122 \mathrm{X}-0.0002 \mathrm{X}^{2} * *$ & 0.69 \\
\hline Summer & $0.0^{\mathrm{E}}$ & Coated & $21.3^{\mathrm{B}}$ & $13.3^{\mathrm{C}}$ & $10.7^{\mathrm{D}}$ & 0.8 & $\hat{\mathrm{Y}}=1.74+0.1018 \mathrm{X}-0.0001 \mathrm{X}^{2 * *}$ & 0.71 \\
\hline$A_{u}$ & $0 \Omega D$ & Common & $14.3^{\mathrm{A}}$ & $3.2^{\mathrm{C}}$ & $4.3^{\mathrm{C}}$ & & $\hat{\mathrm{Y}}=1.87+0.0505 \mathrm{X}-0.0001 \mathrm{X}^{2} *$ & 0.38 \\
\hline Autumn 2 & $0.0^{\mathrm{D}}$ & Coated & $7.1^{\mathrm{B}}$ & $4.4^{\mathrm{C}}$ & $5.9^{\mathrm{B}}$ & 0.4 & $\hat{\mathrm{Y}}=0.71+0.0285 \mathrm{X}-0.00004 \mathrm{X}^{2} * *$ & 0.58 \\
\hline
\end{tabular}

Mean values within the same station followed by the same capital letter do not differ by PDIFF ( $>>0.05$ ). SEM: standard error of the mean. Autumn 1 (4/25/2014 to 6/21/2014), Winter (6/21/2014 to 9/22/2014), Spring (9/22/2014 to 12/21/2014, Summer 2014 $(12 / 21 / 2014$ to $03 / 20 / 2015)$ and Autumn $2(03 / 20 / 2015$ to $06 / 21 / 2015) .{ }^{*}(\mathrm{p}<0.05)$ and $* *(\mathrm{p}<0.01)$.

Higher nitrogen use efficiency under lower $\mathrm{N}$ dose $\left(200 \mathrm{~kg} \mathrm{ha}^{-1}\right.$ year $\left.^{-1}\right)$ of common urea in winter, summer and autumn 2 and under the highest $\mathrm{N}$ dose $\left(600 \mathrm{~kg} \mathrm{ha}^{-1}\right.$ year-1) of coated urea during autumn 1, winter and autumn 2 (Table 4) reveals that there was a beneficial response to the use of coated urea at a higher $\mathrm{N}$ dose possibly because this source promoted greater control of $\mathrm{N}$ availability for plants at the time at which this nutrient was subjected to greater losses due to adverse weather conditions. This occurred in autumn 1 and early winter due to high rainfall (Table 1) and average 
maximum and minimum temperatures of 27.8 and $17.9{ }^{\circ} \mathrm{C}$, respectively. Although during most of the winter season there was low precipitation (Table 1), precipitation reflex in autumn 1 favored the lowest water deficit value and, consequently, soil moisture maintenance in the winter season. In autumn 2, there was low rainfall, but the water deficit was low compared to spring and summer, which may have favored the lower loss of soil moisture. In addition, the average maximum and minimum temperatures of 28 and $18.5^{\circ} \mathrm{C}$, respectively, benefited the action of coated urea. In addition, regression analysis of this variable revealed higher values of the estimated maximum points for coated urea in relation to common urea during all seasons in which there was a quadratic positive effect, as well as the greater effect of the use of coated urea in the winter (positive linear effect) verified only for this source of urea. This shows a greater overall benefit of the use of this urea source in relation to common urea for the nitrogen use efficiency during all seasons of the year.

There was an effect $(\mathrm{p}<0.05)$ of interaction between dose, urea source and seasons of the year for the dry matter (DM) and crude protein (CP) contents of Massai grass during the autumn, winter and spring of 2014 and the summer and fall of 2015 (Table 5). Higher DM contents were obtained for the control treatment in all seasons. A linear negative effect was observed only in the summer for coated urea, already for all the other stations, and for both sources of urea, negative quadratic effects were verified. Higher values of dry matter were obtained in the autumn/winter and autumn 2 seasons. Reductions in DM content due to the increase in nitrogen fertilization in all seasons were due to the effect of nitrogen fertilization combined with the management cut by $95 \%$ light interception to promote faster plant growth and consequently increase the frequency of cutting, resulting in more tender plants, i.e., renewal of younger tissues with more soluble components. This effect is probably characterized by the higher proportion of leaves (mean of $82.0 \%$ ) in relation to the total forage produced in the present experiment (Table 2), which corroborates the results of Sousa et al. (2010), who also observed a reduction in dry matter contents with increased leaf participation under increasing doses of $\mathrm{N}$.

Higher values of CP were obtained for coated urea than for common urea, with higher average values in spring (11.8\%) and summer (10.8\%) and lower values in autumn/winter $(9.1 \%)$, with emphasis on the highest $\mathrm{N}$ dose $\left(600 \mathrm{~kg} \mathrm{ha}^{-1}\right.$ year $\left.{ }^{-1}\right)$. There was an increase in CP contents with the increase in $\mathrm{N}$ doses (positive linear effect) in all seasons. Therefore, the maximum value of this variable was also not obtained in the regression analysis for any of the season or urea sources studied, even under the effect of the maximum dose of $\mathrm{N}$ evaluated, as well as forage accumulation rate (Table 4). The effect of nitrogen on the growth of fodder is that it stimulates the tillering and emergence of new organs in the plant, which are rich in $\mathrm{N}$ because they contain compounds (proteins, chlorophyll, amino acids and peptides) with a high concentration of this nutrient (SCHLICHTING et al., 2015). In the present experiment, the highest levels of $\mathrm{CP}$ were verified using coated urea $(10.4 \%)$ than using common urea (9.41\%), differing from the results obtained by Lima et al. (2016), who did not verify the source effect in CP contents. In the present experiment, the mean CP levels were above 7\%, except for the control treatment, and therefore can be considered adequate to meet the required minimum of this nutrient, as indicated by Van Soest (1994). 
Table 5. Dry matter and crude protein contents of Massai grass as a function of urea sources; nitrogen doses; and seasons autumn/winter and spring of 2014 and summer and autumn (autumn 2) of 2015.

\begin{tabular}{|c|c|c|c|c|c|c|c|c|}
\hline \multirow{2}{*}{ Season } & \multicolumn{5}{|c|}{$\mathrm{N}$ doses $\left(\mathrm{kg} \mathrm{ha}^{-1} \mathrm{yr}^{-1}\right)$} & \multirow{2}{*}{ SEM } & \multirow{2}{*}{ Equations } & \multirow{2}{*}{$\mathrm{R}^{2}$} \\
\hline & 0 & Urea & 200 & 400 & 600 & & & \\
\hline \multicolumn{9}{|c|}{ Dry matter $(\%)$} \\
\hline Aut./ & & Common & $26.4^{\mathrm{D}}$ & $28.1^{\mathrm{BCD}}$ & $29.7^{\mathrm{BCD}}$ & \multirow{2}{*}{1.1} & $\hat{\mathrm{Y}}=56.20-0.165 \mathrm{X}+0.0002 \mathrm{X}^{2} * *$ & 0.87 \\
\hline Wint. & $58,3^{\mathrm{A}}$ & Coated & $30.7^{\mathrm{B}}$ & $27.0^{\mathrm{CD}}$ & $29.3^{\mathrm{CD}}$ & & $\hat{\mathrm{Y}}=57.23-0.156 \mathrm{X}+0.0002 \mathrm{X}^{2} * *$ & 0.94 \\
\hline \multirow[b]{2}{*}{ Spr. } & \multirow{2}{*}{$37.9^{\mathrm{A}}$} & Common & $36.0^{\mathrm{A}}$ & $30.7^{\mathrm{B}}$ & $31.9^{\mathrm{B}}$ & \multirow{2}{*}{1.2} & $\hat{\mathrm{Y}}=38.37-0.023 \mathrm{X}+0.00002 \mathrm{X}^{2} * *$ & 0.52 \\
\hline & & Coated & $32.2^{\mathrm{B}}$ & $32.5^{\mathrm{B}}$ & $31.1^{\mathrm{B}}$ & & $\hat{\mathrm{Y}}=37.49-0.026 \mathrm{X}+0.000027 \mathrm{X}^{2} *$ & 0.44 \\
\hline \multirow{2}{*}{ Sum. } & \multirow{2}{*}{$27.1^{\mathrm{A}}$} & Common & $25.6^{\mathrm{A}}$ & $21.7^{\mathrm{C}}$ & $22.0^{\mathrm{C}}$ & \multirow{2}{*}{0.7} & $\hat{Y}=27.45-0.017 X+0.000012 X^{2} * *$ & 0.63 \\
\hline & & Coated & $23.43^{\mathrm{BC}}$ & $25.1^{\mathrm{AB}}$ & $22.9^{\mathrm{C}}$ & & $\hat{Y}=26.30-0.0055 X^{*}$ & 0.34 \\
\hline \multirow{2}{*}{ Aut. 2} & \multirow{2}{*}{$53.9^{\mathrm{A}}$} & Common & $29.8^{\mathrm{BC}}$ & $28.1^{\mathrm{C}}$ & $31.8^{\mathrm{B}}$ & \multirow{2}{*}{0.8} & $\hat{Y}=52.08-0.0133 X+0.0002 X^{2} * *$ & 0.94 \\
\hline & & Coated & $25.8^{\mathrm{D}}$ & $27.9^{\mathrm{CD}}$ & $25.9^{\mathrm{D}}$ & & $\hat{\mathrm{Y}}=50.95-0.1317 \mathrm{X}+0.0002 \mathrm{X}^{2 * *}$ & 0.85 \\
\hline \multicolumn{9}{|c|}{ Crude protein (\%DM) } \\
\hline \multirow{2}{*}{$\begin{array}{l}\text { Aut./ } \\
\text { Wint. }\end{array}$} & \multirow{2}{*}{$5.3^{\mathrm{C}}$} & Common & $7.7^{\mathrm{B}}$ & $8.5^{\text {B }}$ & $11.8^{\mathrm{A}}$ & \multirow{2}{*}{0.3} & $\hat{\mathrm{Y}}=5.27+0.0102 \mathrm{X} * *$ & 0.89 \\
\hline & & Coated & $8.1^{\mathrm{B}}$ & $11.4^{\mathrm{A}}$ & $11.8^{\mathrm{A}}$ & & $\hat{\mathrm{Y}}=5.72+0.0114 \mathrm{X} * *$ & 0.89 \\
\hline \multirow{2}{*}{ Spr. } & \multirow{2}{*}{$6.0^{\mathrm{D}}$} & Common & $6.6^{\mathrm{D}}$ & $13.4^{\mathrm{B}}$ & $17.0^{\mathrm{A}}$ & \multirow{2}{*}{0.6} & $\hat{\mathrm{Y}}=4.52+0.0205 \mathrm{X} * *$ & 0.88 \\
\hline & & Coated & $10.1^{\mathrm{C}}$ & $14.3^{\mathrm{B}}$ & $16.6^{\mathrm{A}}$ & & $\hat{\mathrm{Y}}=6.35+0.018 \mathrm{X} * *$ & 0.90 \\
\hline \multirow{2}{*}{ Sum. } & \multirow{2}{*}{$5.3^{\mathrm{E}}$} & Common & $8.1^{\mathrm{D}}$ & $12.4^{\mathrm{B}}$ & $13.6^{\mathrm{AB}}$ & \multirow{2}{*}{0.5} & $\hat{\mathrm{Y}}=5.40+0.0142 \mathrm{X} * *$ & 0.96 \\
\hline & & Coated & $9.8^{\mathrm{C}}$ & $13.4^{\mathrm{B}}$ & $14.9^{\mathrm{A}}$ & & $\hat{\mathrm{Y}}=6.00+0.0162 \mathrm{X} * *$ & 0.87 \\
\hline \multirow{2}{*}{ Aut. 2} & \multirow{2}{*}{$5.8^{\mathrm{C}}$} & Common & $7.3^{\mathrm{C}}$ & $11.2^{\mathrm{AB}}$ & $10.9^{\mathrm{AB}}$ & \multirow[b]{2}{*}{0.7} & $\hat{\mathrm{Y}}=6.04+0.0093 \mathrm{X} * *$ & 0.64 \\
\hline & & Coated & $9.6^{\mathrm{B}}$ & $12.6^{\mathrm{A}}$ & $11.6^{\mathrm{A}}$ & & $\hat{\mathrm{Y}}=6.63+0.0106 \mathrm{X} * *$ & 0.60 \\
\hline
\end{tabular}

Mean values within the same station followed by the same capital letter do not differ by PDIFF ( $>0.05)$. SEM: standard error of the mean. Autumn/Winter (04/25/2014 to 09/22/2014), Spring (22/09/2014 to $12 / 21 / 2014)$, Summer (12/21/2014 to 20/03/2015) and Autumn $2(20 / 03 / 2015$ to $21 / 06 / 2015) . *(\mathrm{p}<0.05)$ and $* *(\mathrm{p}<0.01)$.

There was an interaction $(\mathrm{p}<0.05)$ between $\mathrm{N}$ doses and season of the year for neutral detergent fiber (NDF) (Table 6). Most NDF values were verified for the control treatment, and the increase in $\mathrm{N}$ doses led to a reduction in the levels of this variable (negative linear effect) in almost all seasons (autumn/winter, spring and summer), except for autumn 2, in which no influence of $\mathrm{N}$ dose (mean of $72.6 \% \mathrm{NDF})$ was verified. The reduction of NDF values (from 75.5 to $70.6 \%$ ) with increasing $\mathrm{N}$ doses (zero and $600 \mathrm{~kg} \mathrm{ha}^{-1} \mathrm{yr}^{-1}$, respectively) in the present experiment corroborates the results obtained by Vitor et al. (2009), who reported a reduction from 76.9 to $72.0 \%$ for the highest $\mathrm{N}$ dose (from 100 to $700 \mathrm{~kg} \mathrm{ha}^{-1}$, respectively). In autumn 2, this variable remained constant with increasing $\mathrm{N}$ doses (Table 6), which may be justified by the reduction in rainfall and temperature in fall.
The mean NDF values obtained in this study (72.9\%) were lower than those verified by Geron et al. (2014) for Massai (76.8\%), Marandu (78.6\%) and Humidícola (75.0\%) and Mombaça grasses (73.1\%). However, the values obtained in the present experiment for Massai grass are considered high even for tropical forages, since according to Van Soest (1994), values above 55 to $60 \%$ NDF in dry matter limit the voluntary consumption of forage. This is due to the anatomical structure of Massai grass, called the girder I, which consists of an arrangement of sclerenchymatic cells between the epidermal cells and vascular bundle sheaths in the leaf blades (LEMPP, 2007), which hinders or prevents the removal of the epidermis by digestion or by physical force and limits the voluntary consumption by the animals (EUCLIDES et al., 2008; VOLPE et al., 2008). 
Table 6. Neutral detergent fiber of Massai grass as a function of nitrogen doses in the autumn/winter and spring of 2014 and the summer and autumn of 2015.

\begin{tabular}{lccccccc}
\hline \multirow{2}{*}{ Season } & \multicolumn{9}{c}{$\mathrm{N}$ doses $\left(\mathrm{kg} \mathrm{ha}^{-1} \mathrm{yr}^{-1}\right)$} & \multirow{2}{*}{ SEM } & \multirow{2}{*}{ Equations } & \multirow{2}{*}{$\mathrm{R}^{2}$} \\
\cline { 2 - 5 } & 0 & 200 & 400 & 600 & & \\
\hline Autumn/winter & $75.01^{\mathrm{B}}$ & $74.67^{\mathrm{A}}$ & $73.13^{\mathrm{A}}$ & $72.67^{\mathrm{A}}$ & 0.43 & $\hat{\mathrm{Y}}=75.233-0.0045 \mathrm{X} * *$ & 0.34 \\
Spring & $75.20^{\mathrm{BC}}$ & $73.09^{\mathrm{AB}}$ & $71.26^{\mathrm{B}}$ & $67.50^{\mathrm{C}}$ & 0.88 & $\hat{\mathrm{Y}}=75.659-0.0128 \mathrm{X} * *$ & 0.48 \\
Summer & $78.77^{\mathrm{A}}$ & $74.27^{\mathrm{A}}$ & $71.99^{\mathrm{AB}}$ & $69.67^{\mathrm{B}}$ & 0.51 & $\hat{\mathrm{Y}}=77.754-0.014 \mathrm{X} * *$ & 0.72 \\
Autumn 2 & $72.86^{\mathrm{C}}$ & $71.99^{\mathrm{B}}$ & $72.19^{\mathrm{AB}}$ & $72.63^{\mathrm{A}}$ & 0.60 & $\hat{\mathrm{Y}}=72.58$ & - \\
\hline
\end{tabular}

Means arranged in the same column followed by the same capital letter do not differ by PDIFF ( $>0.05$ ). SEM: standard error of the mean. Autumn/Winter (04/25/2014 to 09/22/2014), Spring (22/09/2014 to 12/21/2014), Summer (12/21/2014 to 20/03/2015) and Autumn $2(20 / 03 / 2015$ to $21 / 06 / 2015) . *(p<0.05)$ and $* *(p<0.01)$.

\section{Conclusions}

The use of nitrogen fertilization, up to $600 \mathrm{~kg}$ ha $^{-1}$ year ${ }^{-1}$, benefits the morphological and chemical compositions of the forage and the structural characteristics and forage accumulation of Massai grass.

Higher nitrogen use efficiency is obtained with coated urea than with common urea in all seasons of the year, when increasing $\mathrm{N}$ doses are applied in Massai grass pastures.

\section{Acknowledgements}

To the Coordenação de Aperfeiçoamento de Pessoal de Nível Superior (CAPES) for the granting of the scholarship during the Master's Course in the Animal Science Postgraduate Program of UFRRJ.

\section{References}

ALCÂNTARA, D.; SCHUELER, A. S. Water management and sustainability: global challenges and local responses from the case study of Seropédica, Metropolitan Region of Rio de Janeiro. Cadernos Metrópole, São Paulo, v. 17, n. 33, p. 109-126, 2015.

ASSOCIATION OF OFFICIAL ANALITICAL CHEMISTRY - AOAC. Official methods of analysis. $19^{\text {th }}$ ed. Washington: 2000. 1219 p.

AZEEM, B.; KUSHAARI, K.; MAN, Z. B.; BASIT, A.; THANH, T. H. Review on materials \& methods to produce controlled release coated urea fertilizer. Journal of Controlled Release, Amsterdam, v. 181, n. 1, p. 11-21,
2014.

BRÂNCIO, P. A.; EUCLIDES, V. P. B.; NASCIMENTO JÚNIOR, D.; FONSECA, D. M.; ALMEIDA, R. G.; MACEDO, M. C. M.; BARBOSA, R. A. Avaliação de três cultivares de Panicum maximum Jacq. sob pastejo: disponibilidade de forragem, altura do resíduo póspastejo e participação de folhas, colmos e material morto. Revista Brasileira de Zootecnia, Viçosa, MG, v. 32, n. 1, p. 55-63, 2003.

CARVALHO, D. F.; SILVA, D. G.; SOUZA, A. P.; GOMES, D. P.; ROCHA, H. Coeficientes da equação de Angström-Prescott e sua influência na evapotranspiração de referência em Seropédica, RJ. Revista Brasileira de Engenharia Agrícola e Ambiental, Campina Grande, v. 15, n. 8, p. 108-116, 2011.

CASTAGNARA, D. D.; MESQUITA, E. E.; NERES, M. A. Valor nutricional e características estruturais de gramíneas tropicais sob adubação nitrogenada. Archivos de Zootecnia, Córdoba, v. 60, n. 232, p. 931-942, 2011.

DOUGHERTY, C. T.; RHYKERD, C. L. The role of nitrogen in forage-animal production. In: HEATH, M. E.; BARNES, R. F.; METCALFE, D. S. (Ed.). Forages: the science of grassland agriculture. Ames: Iowa State University Press, 1985. p. 318-325.

EMERENCIANO NETO, J. V.; DIFANTE, G. S.; MONTAGNER, D. B.; BEZERRA, M. G. S.; GALVÃO, R. C. P.; VASCONCELOS, R. I. G. Características estruturais do dossel e acúmulo de forragem em gramíneas tropicais, sob lotação intermitente e pastejada por ovinos. Bioscience Journal, Uberlândia, v. 29, n. 4, p. 962-973, 2013.

EMERENCIANO NETO, J. V.; PEREIRA, G. F.; DIFANTE, G. S. Produção e estrutura de pastos de capim-massai adubado com dejetos da produção animal. Boletim de Indústria Animal, Nova Odessa, v. 73, n. 2, p. 111-117, 2016. 
EUCLIDES, V. P. B.; MACEDO, M. C. M.; ZIMMER, A. H.; OLIVEIRA, M. P. Avaliação dos capins Mombaça e Massai sob pastejo. Revista Brasileira de Zootecnia, Viçosa, MG, v. 37, n. 1, p. 18-26, 2008.

GAGNON, B.; ZIADI, N.; GRANT, C. Urea fertilizer forms affevt grain corn yield and nitrogen use efficiency. Canadian Journal of Soil Science, Ottawa, v. 92, n. 2, p. 341-351, 2012.

GAO, X.; LI, C.; ZHANG, M.; WANG, R.; CHEN, B. Controlled release urea improved the nitrogen use efficiency, yield and quality of potato (Solanum tuberosum L.) on silt loamy soil. Field Crops Research, Amsterdam, v. 181, p. 60-68, 2015.

GERON, L. J. V.; CABRAL, L. S.; TRAUTMANNMACHADO, R. J.; ZEOULA, L. M.; OLIVEIRA, E. B.; GARCIA, J.; GONÇALVES, M. R.; AGUIAR, R. P. S. Avaliação do teor de fibra em detergente neutro e ácido por meio de diferentes procedimentos aplicados às plantas forrageiras. Semina: Ciências Agrárias, Londrina, v. 35, n. 3, p. 1533-1542, 2014.

GIRARDI, E. A.; MOURÃO FILHO, F. A. A. Emprego de fertilizantes de liberação lenta na formação de pomares de citros. Revista Laranja, Cordeirópolis, v. 24, n. 2, p. 507-518, 2003.

GRANT, C. A.; WU, R.; SELLES, F. Crop yield and nitrogen concentration with controlled release urea and split applications of nitrogen as compared to noncoated urea applied at seeding. Field Crops Research, Amsterdam, v. 127, p. 170-180, 2012.

HILL, M. J.; WATSON, R. W. The effect of differences in intensity and frequency of defoliation on the growth of Sirolan phalaris in the field. Australian Journal of Agricultural Research, Clayton South, v. 40, n. 2, p. 345$352,1989$.

HODGSON, J. Grazing management: science into practice. New York: John Wiley \& Sons, Inc., Longman Scientific \& Technical. 1990. 203 p.

KAPPES, C.; CARVALHO, M. A. C.; YAMASHITA, O. M.; SILVA, J. A. N. Influência do nitrogênio no desempenho produtivo do milho cultivado na segunda safra em sucessão à soja. Pesquisa Agropecuária Tropical, Goiânia, v. 39, n. 3, p. 251-259, 2009.

LAWLOR, O. W. Photosynthesis: metabolism, control and physiology. England: Longman Scientific \& Technical, 1987. 262 p.

LEMPP, B. Avanços metodológicos da microscopia na avaliação de alimentos. Revista Brasileira de Zootecnia, Viçosa, MG, v. 36, p. 315-329, 2007. Suplemento Especial.
LIMA, J. E. S.; NASCENTE, A. S.; LEANDRO, W. M.; SILVEIRA, P. M. Urochloa ruziziensis responses to sources and doses of urea. Revista Brasileira de Engenharia Agrícola e Ambiental, Campina Grande, v. 20, n. 5, p. 401-407, 2016.

LOPES, M. N.; CÂNDIDO, M. J. D.; POMPEU, R. C. F. F.; SILVA, R. G.; BEZERRA, F. M. L. Componentes estruturais do resíduo pós-corte em capim-massai adubado com cinco doses de nitrogênio. Revista Ciência Agronômica, Fortaleza, v. 42, n. 2, p. 518-525, 2011.

LUNA, A. A.; DIFANTE, G. S.; MONTAGNER, D. B.; EMERENCIANO NETO, J. V.; ARAÚJO, I. M. M.; OLIVEIRA, L. E. C. Características morfogênicas e acúmulo de forragem de gramíneas forrageiras sob corte. Bioscience Journal, Uberlândia, v. 30, n. 6, p. 18031810, 2014.

MACEDO, C. H. O.; ANDRADE, A. P.; SANTOS, E. M.; SILVA, D. S.; SILVA, T. C.; EDVAN, R. L. Perfil fermentativo e composição bromatológica de silagens de sorgo em função da adubação nitrogenada. Revista Brasileira de Saúde e Produção Animal, Salvador, v. 13, n. 2, p. 371-382, 2012.

NASH, P. R.; NELSON, K. A.; MOTAVALLI, P. P.; MEINHARDT, C. Effects of polymer - coated urea application ratios and dates on wheat and subsequent double-crop soybean. Agronomy Journal, Madison, v. 104, n. 4, p. 1074-1084, 2012.

OLIVEIRA JÚNIOR, J. F.; DELGADO, R. C.; GOIS, G.; LANNES, A.; DIAS, O. F.; SOUZA, J. C.; SOUZA, M. Análise da precipitação e sua relação com sistemas meteorológicos em Seropédica, Rio de Janeiro. Floresta e Ambiente, Seropédica, v. 21, n. 2, p. 140-149, 2014.

PORTZ, A.; RESENDE, A. S.; TEIXEIRA, A. J.; ABBOUD, A. C. S.; MARTINS, C. A. C.; CARVALHO, C. A. B.; LIMA, E.; ZONTA, E.; PEREIRA, J. B. A.; BALIEIRO, F. C.; ALMEIDA, J. C. C.; SOUZA, J. F.; GUERRA, J. G. M.; MACEDO, J. R.; SOUZA, J. N.; FREIRE, L. R.; VASCONCELOS, M. A. S.; LEAL, M. A. A.; FERREIRA, M. B. C.; MANHÃES, M.; GOUVEA, R. F.; BUSQUET, R. N. B.; BHERING, S. B. Recomendações de adubos, corretivos e de manejo da matéria orgânica para as principais culturas de Estado do Rio de Janeiro. In: FREIRE, L. R.; BALIEIRO, F. C.; ANJOS, L. H. C.; PEREIRA, M. G.; LIMA, E.; GUERRA, J. G. M.; FERREIRA, M. B. C.; LEAL, M. A. A.; CAMPOS, D. V. B.; POLIDORO, J. C. Manual de calagem e adubação do Estado do Rio de Janeiro. Seropédica: UFRRJ, 2013. cap. 14, p. 257-414.

RAMOS, D. P.; CASTRO, A. F.; CAMARGO, M. N. Levantamento detalhado de solos da área da Universidade 
Federal Rural do Rio de Janeiro. Pesquisa Agropecuária Brasileira, Brasília, v. 8, n. 6, p. 1-27, 1973.

SANTINI, J. M. K.; PERIN, A.; COAGUILA, D. N.; VALDERRAMA, M.; DUPAS, E.; SANTOS, C. G.; SILVA, V. M.; BUZETTI, S. Adubação nitrogenada na implantação de Urochloa brizantha cv. Xaraés no cerrado: características nutricionais-parte 2. Revista Brasileira de Engenharia de Biossistemas, Tupã, v. 10, n. 2, p. 140-153, 2016.

SCHLICHTING, A. F.; SILVA, E. M. B.; SILVA, M. C. Eficiência de medidores portáteis de clorofila na avaliação do estado nutricional de plantas de trigo. Revista Brasileira de Engenharia Agrícola e Ambiental, Campina Grande, v. 19, n. 12, p. 1148-1151, 2015.

SOUSA, R. S.; PIRES, A. J. V.; CARVALHO, G. G. P. Composição química de capim-tanzânia adubado com nitrogênio e fósforo. Revista Brasileira de Zootecnia, Viçosa, MG, v. 39, n. 6, p. 1200-1205, 2010.

THORNTHWAITE, C. W.; MATHER, J. R. The water balance. Centerton: Drexel Institute of Technology, Laboratory of Climatology, 1955. 104 p. (Publications in Climatology, v. VIII, n. 1).

VAN SOEST, P. J. Nutrition ecology of the ruminant. Ithaca: Comstock Publishing Associates, 1994. 476 p.

VAN SOEST, P. J.; ROBERTSON, J. B.; LEWIS, B. A. Methods for dietary fiber, neutral detergent fiber, and nonstarch polysaccharides in relation to animal nutrition. Journal Dairy Science, Champaign, v. 74, n. 10, p. 35833597, 1991.

VITOR, C. M. T.; FONSECA, D. M.; CÓSER, A. C.; MARTINS, C. E.; NASCIMENTO JÚNIOR, D.; JÚNIOR, J. I. R. Produção de matéria seca e valor nutritivo de pastagem de capim-elefante sob irrigação e adubação nitrogenada. Revista Brasileira de Zootecnia, Viçosa, MG, v. 38, n. 3, p. 435-442, 2009.

VITOR, C. M. T.; FONSECA, D. M.; MOREIRA, L. M.; FAGUNDES, J. L.; NASCIMENTO JÚNIOR, D.; JÚNIOR, J. I. R.; PEREIRA, A. L. Rendimento e composição química do capim-braquiária introduzido em pastagem degradada de capim-gordura. Revista Brasileira de Zootecnia, Viçosa, MG, v. 37, n. 12, p. 2107-2114, 2008.

VOLPE, E.; MARCHETTI, M. E.; MACEDO, M. C. M.; LEMPP, B. Acúmulo de forragem e características do solo e da planta no estabelecimento de capim-massai com diferentes níveis de saturação por bases, fósforo e nitrogênio. Revista Brasileira de Zootecnia, Viçosa, MG, v. 37, n. 2, p. 228-237, 2008.

WILSON, M. L.; ROSEN, C. J.; MONCRIEF, J. F. Potato response to a polymer-coated urea on an irrigated, coarse-texture soil. Agronomy Journal, Madison, v. 101, n. 4, p. 897-905, 2009.

WOLFINGER, R. D. Covariance structure selection in general mixed models. Communications in Statistics Simulation and Computation, London, v. 22, n. 4, p. 1079-1106, 1993.

YANG, Y.; ZHANG, M.; ZHENG, L.; CHENG, D. D.; LIU, M.; GENG, Y. Q. Controlled release ureia improved nitrogen use efficiency, yield and quality of wheat. Agronomy Journal, Madison, v. 103, n. 2, p. 479-485, 2011.

ZIADI, N.; GRANT, C. A.; SAMON, N.; NYIRANEZA, J.; BÉLANGER, G.; PARENT, L-E. Efficiency of controlled-release urea for a potato production system in Quebec, Canada. Agronomy Journal, Madison, v. 103, n. 1, p. 60-66, 2011. 